INDEPENDENT JOURNAL OF MANAGEMENT \& PRODUCTION (IJM\&P)

http://www.ijmp.jor.br

V. 10, n. 5, September-October 2019

ISSN: 2236-269X

DOI: $10.14807 /$ ijmp.v10i5.926

\title{
ROAD TRANSPORT INFRASTRUCTURE: A LONGITUDINAL CASE STUDY (2009-2017)
}

Rodrigo Ribeiro Oliveira

Federal Institute of Education, Science and Technology of São

Paulo (IFSP), Brazil

E-mail: rodrigoribeirosp@hotmail.com

Renata Schirrmeister Pontifical Catholic University of São Paulo (PUC-SP), Brazil

E-mail: rschirrmeister@gmail.com

Fernando Nascimento Zatta Mackenzie Presbiterian University - Mackenzie, Brazil

E-mail: zatta@hmzconsulting.com.br

Rodrigo Randow Freitas Federal University of Espírito Santo (UFES), Brazil E-mail: rodrigo.r.freitas@ufes.br

Wellington Gonçalves Federal University of Espírito Santo (UFES), Brazil E-mail: wellington.goncalves@ufes.br

Submission: $12 / 08 / 2018$

Revision: 12/31/2018 Accept: 2/08/2018

\section{ABSTRACT}

This article investigates the economic gains with the reduction of logistics costs after the asphalt pavement of the highway MT 235 for a Brazilian crystal sugar and alcohol industry. Investment in infrastructure is an attribute that increases economic growth and increases the competitiveness of companies. As far as road transport infrastructure is concerned, the problems are not limited to a specific area, but stretches of highways, which link urban transportation and ports to the generation and transmission of electricity, among others. Only $12.2 \%$ of Brazilian highways are paved. This work is the result of a longitudinal case study with participant observation, in a timeline from 2009 to 2017. 
It was possible to identify that, after improvements in road transport infrastructure, the asphalt pavement of the highway MT 235 made possible earnings in travel time and a decrease in logistics costs, which led to the closure of the activities of one of the subsidiaries of the company studied, located in Manaus (Amazonas), in 2009. With the benefits of the asphalt pavement of the MT 235, in 2017 we found that sales volume increased $483 \%$ to 2009 , logistics costs have been significantly reduced concerning gross revenues, maintaining an average of $11.58 \%$. In 2017, the logistics costs of the company studied were $12.61 \%$ versus $20.7 \%$ from the group of Brazilian agribusiness companies. The findings show that investments in road transport infrastructure are crucial when it comes to fostering trade and competitiveness of domestic products in international markets, by reducing logistics costs.

Keywords: Brazilian infrastructure; road transport; logistical challenges; logistics costs; reduction of logistics costs

\section{INTRODUCTION}

According to Fay et al. (2017), Latin America and the Caribbean do not have the necessary basic infrastructure, when one considers the level of income and the real and expected demand. These regions have logistical infrastructure below what is considered necessary to promote social integration to achieve a higher level of growth and prosperity.

For example, geographic factors and transport infrastructure are two of the main factors influencing international competitiveness (BASSASSI et al., 2015). In this way, it can be seen that there is a direct relationship between the precariousness of Brazilian Highways and the social, environmental, and economic issues, for example, accidents that result in deaths and unnecessary consumption of fuels, mainly diesel oil, affecting the cost structure and increasing the emissions through the emission of polluting gases.

Regarding the lack of infrastructure, in 2016, on the policed federal highways, there were 96,362 accidents resulting in 6,398 deaths recorded at a cost of $R \$ 10.88$ billion for the country, a figure that is higher than the investment made in highways in 2015 , which was of the order of $\mathrm{R} \$ 8.61$ billion (CNT, 2017). 
In a country of continental dimensions such as Brazil, the knowledge and application of modern logistics practices should have as primary objective to manage compatible costs to maintain the continuity of productive, commercial and distribution activities. In particular, the agribusiness sector is an essential follow-up for the development of the national economy. From this perspective, the country needs to increase its investments in infrastructure in order to strengthen the growth of national production and consequently its productivity. However, it is a matter of concern, since Brazil currently occupies the 116th position regarding infrastructure quality, in a list of 138 countries (OECD, 2018).

Given this scenario, the main focus of this article is to investigate the economic gains arising from the asphalt paving process of the MT 235 highway, in the period between 2009 and 2017, in order to meet the demand of a sugar and alcohol industry located in the Mato Grosso region. It is structured in five sessions, considering this introductory section. The next section deals with methodological procedures, the fourth section discusses the results of field research, and the fifth section presents the final considerations, contributions, limitations and suggestions for future research.

\section{THEORETICAL FRAMEWORK}

In recent years, logistics has been gaining ground in the discussions within the organizations with a broad contribution of the academy, since the treatment of problems related to this theme suggest significant gains for the business organizations, especially when considering scenarios of constant economic crises and complexity of the competition between companies, where the market becomes increasingly demanding.

In this scenario, companies need to identify ways to remain active and remain competitive by reducing their logistics costs (NUNES et al., 2018). For example, organizations need to arrange the movement of raw materials for their operations, and finished products to be destined to the retail and wholesale markets, as well as organize their protection, storage, control and distribution of their finished product stocks (SLACK, 1996).

Ballou (2006) argues that logistics is about creating value for customers and suppliers of the company, and value for all those who have direct interests in it. Thus, 
any product or service loses almost its full value when it is not available to customers at the right time and place.

In Brazil, one of the primary modalities is road transport, that is, the modal supports the more significant part of the movement of cargoes and passengers. This situation is expected to remain so for many years still mainly, to offer competitive prices in comparison to the other modes, even considering the long distances, despite the environmental and economic externalities involved (ASSIS; MARCALET; DALO, 2017; BOULOS FILHO et al., 2015).

The road modal is used to dispose of $75.9 \%$ of production within the country, followed by the maritime modal with $9.2 \%$ partition, the air modal with the participation of $5.8 \%$, the rail modal with $5.4 \%$, cabotage with $3 \%$ and the waterway model with participation of $0.7 \%$ (FDC, 2017). However, despite the significant participation of the modal road, as we have just verified, only $12.2 \%$ of Brazilian highways are paved (CNT, 2017).

Considering the waterways, Brazil has more than 39,146 traffic miles, which includes rivers, lakes, and lagoons; however, just over 8,077 miles are used for navigation. For comparison purposes, the United States of America (USA) uses about 13,760 miles (TOLOI et al., 2016).

According to Faria, Souza and Vieira (2015), the best logistics performances are generally those of Germany, USA, and Japan, followed by the performances presented by the Netherlands, which are considered the main competitors of Brazil in international trade.

Deimling et al (2016) suggests that if there were a disruption of the transportation system, any nation would be literally paralyzed, since when it is considered that transport modes do not constitute an importable good and when including in this analysis countries of continental dimensions as is the case of Brazil, this risk becomes even more critical.

It should also be noted that the modal conditions used directly influence the freight price. The poor conservation of the roadway, for example, dramatically increases vehicle maintenance costs, making transport activity slower, causing more significant exposure to accidents, aggravating logistic inefficiency and directly impacting higher logistics costs. 
Neves (2018) reports that the truck drivers' strike in Brazil in May 2018, also called the Diesel Crisis - caused by the increase in freight prices, as well as influenced by the poor quality of the roads, insecurity and theft of cargo - caused losses in the order of $\mathrm{R} \$ 16$ billion, reinforcing the fact that the high dependence of the road modal became a matter of national security.

It is notorious that Brazil needs to increase its investments in infrastructure to strengthen productivity growth and to obtain a better position compared to the one currently occupied by the country (116th), as a logistical infrastructure, in a list of 138 countries (OECD, 2018).

The low level of investment in infrastructure that characterizes Brazil's economy, and the problems arising therefrom are not limited to an isolated area, but to vast stretches of federal, state and municipal highways, for urban transportation, for ports, and for generation and transmission of electricity (AMANN et al., 2016). However, the main problem is not the low level of investment, but the inability to continue to maintain investment levels permanently (MONTES; REIS, 2011).

According to Assis, Marchetti and Dalto (2017) logistical costs are increased by the preponderant use of the road modal for the transport of cargo over long distances, the lack of quality of the physical infrastructure and management and the difficulties of rational integration of logistics flow between different modes, generating undesirable stocks.

Therefore, it is necessary to apply new competitive strategies, seeking the integration of transport modalities existing and available in Brazil, with the objective of reducing the costs involved in this stage of the production chain. At this threshold, Fay et al. (2017) report that the connection, for example, of rural communities with the "outside world" is essential for inclusion in economic development, since good rural access can increase the welfare of families, facilitate ownership of goods, increase in agricultural productivity and access to essential services (Figure 1).

Counterpoint is the use of waterways which is an essential means of transport for products with low added value and non-expressive costs (TOLOI et al., 2016). However, according to Ballou (2010), the waterway service is limited in scope for many reasons, mainly because it is confined to the interior waterway system, thus requiring the user to be located on its banks or to use another mode of transportation. 


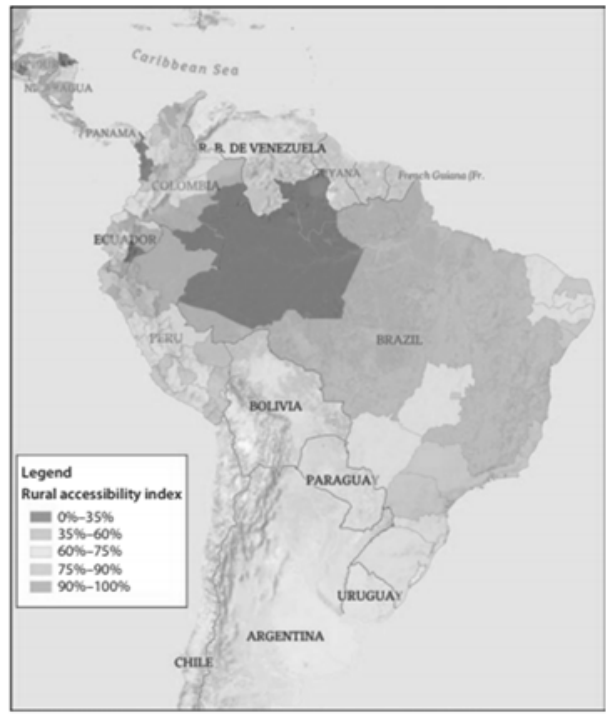

Figure 1: Representation of low population density and transport infrastructure in Latin America. Percentages of the rural population to $2 \mathrm{~km}$ of a road. Source: Fay et al. (2017, p. 25).

Thus, development in logistics and transport infrastructure is crucial when it comes to fostering trade and therefore the competitiveness of domestic products concerning international markets (BASSASSI et al., 2015). In this context, the northern region, besides being the one that has the lowest supply of highways, is the one with the worst conditions, with $81.1 \%$ of the extension classified in 2017 as regular, poor or very poor. The best result was obtained by the southeast region, with 14,260 km evaluated as excellent or good $(48.5 \%)$. In the same classification, the central-west, south and northeast regions obtained: $65.4 \%, 61.7 \%$, and $61.5 \%$, respectively (CNT, 2017).

As an example of competitiveness, as discussed above, in 2015 Brazil exported 54.32 million tons of soybeans, which represented $40.2 \%$ of total world exports. However, even with lower production costs, Brazil's competitive advantages are diminished due to poor product distribution caused by logistic network problems (LOPES et al., 2017).

In summary, based on the above discussion, investment in transport and logistics infrastructure is a critical factor in fostering the development of a country's economy (SKOROBOGATOVA; KUZMINA-MERLINO, 2017) and thus in the case of Brazil, it is necessary to make investments in its logistical modalities, so that an increase in the volume of cargoes can reduce logistical costs (COSTA; MARJOTTAMAISTRO, 2017). 
INDEPENDENT JOURNAL OF MANAGEMENT \& PRODUCTION (IJM\&P)

http://www.ijmp.jor.br

v. 10, n. 5, September-October 2019

ISSN: 2236-269X

DOI: 10.14807/ijmp.v10i5.926

\section{METHODOLOGY}

We use a longitudinal case study with participant observation, which Yin (2010) calls as a special modality, in which the researcher is not only a passive observer, that is, he participates in the process of accumulation of knowledge about the object of study, assuming a variety of functions within the case study, participating in the events surveyed. Participant observation consists of real participation in the life of the community, organization or group in which the research is carried out (GIL, 2009), because the observer assumes, at least to some extent, the role of a group member.

One advantage of conducting longitudinal studies is that it can keep up with changes over time, and ensure possible benefits with an intelligent questioning of past attitudes, history and future expectations (COOPER; SCHINDLER, 2003).

Specifically in this study, one of the researchers participated directly in the observation and activities developed in the investigated sugarcane industry, located in the interior of the Mato Grosso state. This company has been developing activities for the production of crystal sugar and ethanol (fuel alcohol) for more than 30 years. The sugar and alcohol industry operates with approximately 1,400 employees in the harvest period, from April to October, and 800 employees in the off-season from November to March.

Regarding the secondary data, we consult records, reports, spreadsheets, graphs, inventories and other documents related to the monitoring of production, billing, logistics costs and volume of products marketed by the industry. This data collection also counted on a participant and controlled observation about these activities, which took place in January and February of 2018.

\section{CASE STUDY ANALYSIS AND DISCUSSION}

In August 2002, the sugar and alcohol industry began operations in the city of Manaus, capital of the state of Amazonas, located in the Amazon region, through the inauguration of a subsidiary that served to prompt delivery of its products in order to serve its customers better.

In this subsidiary, the sugar-alcohol industry sought to reach a reasonable degree of availability of its products, keeping its stocks to act as buffers between supply and demand (BALLOU, 2010). The extensive use of inventories results in the fact that, on average, they are responsible for consuming approximately one to two- 
thirds of logistics costs, which makes inventory maintenance an essential activity in the production chain, regarding logistics.

However, the high costs associated with the maintenance of stored products, on the whole, correspond, on average, between $25 \%$ and $30 \%$ of the value of the product per year, requiring careful administration. Inventory management involves maintaining the lowest levels while providing the desired availability of the customers.

The great challenge of the sugar and alcohol industry was to meet the demand of its customers during the twelve months of the year. Thus, it was necessary to develop, through logistics, strategic actions of competitiveness to maintain the lung stock of the products in its subsidiary and to be programmed to face yearly susceptible climatic conditions peculiar to the Central-West and Northern regions of Brazil.

The BR-364 Highway that has approximately $60.8 \mathrm{~km}$ is the main route to the transportation of products from the agribusiness and became impassable for approximately four months of the year. It occurs because being in its bed natural, highways constructed without meeting the road rules of geometric design, considerably increasing the transportation time traveled in this stretch, causing a significant increase in transport costs (Figure 2).

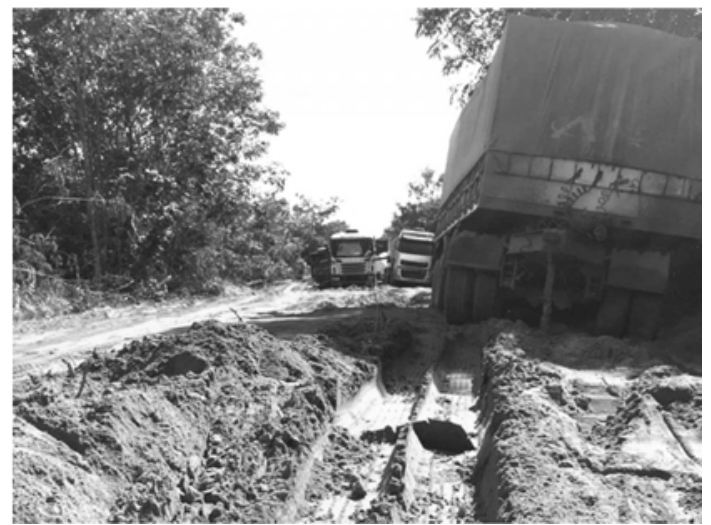

Figure 2: Photographic illustration of the traffic conditions in the Mato Grosso do Sul Highway that persist and generate a state of emergency in the full year of 2018. Source: Gazeta MT (2018).

The road model, which represents the primary means to transport the products of the State of Mato Grosso, still is not currently in good condition, lacking investments in maintenance and modernization of roads (RECH et al., 2017).

It is estimated that in 2017 alone, the transportation sector has an unnecessary consumption of 832.30 million liters of diesel. This waste will cost $R \$ 2.54$ billion to 
transporters. The calculation is made based on the inadequacies found in the pavement (CNT, 2017).

An alternative to the production flow in that region is to transport them to the city of Porto Velho, Capital of the State of Rondônia, where the fluvial port used for loading, unloading, and transportation of products by the Madeira River Waterway is located, a tributary of the bank right of the Amazon River. The Madeira River is a fundamental way of disposing of agricultural production in the states of Rondônia and western Mato Grosso, thus presenting the lowest logistics costs, being the most competitive alternative with external and internal markets (North and Northeast regions of Brazil) and contributing to the development of the Amazon region due to its strategic position.

It should also be noted that river transport has peculiar characteristics due to the period of low water that occurs from July to October. In this period the formation of sandbanks occurs, which alter the favorite navigation channel, which makes transport through large rafts impossible. Therefore, the only alternative is to use smaller-sized ferries, which requires a longer transport time, on average from 7 to 25 days, in addition to the reduction of the load capacity per ferry, which raises costs in the logistics process (Figure 3).

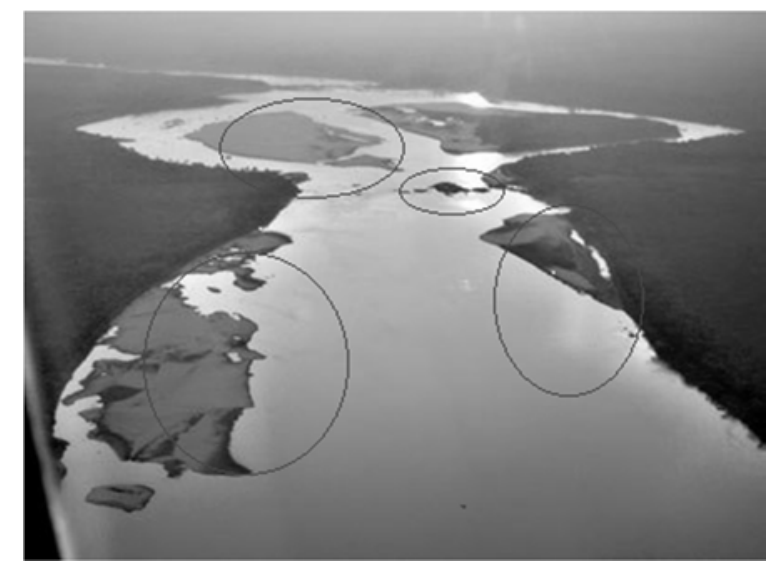

Figure 3: Navigation on the Madeira river is restricted between Porto Velho (Rondônia) and Humaitá (Amazonas)

Source: Portal Amazônia (2016).

The aspects reported were the motivating factors that have led the sugar and alcohol industry to set up a subsidiary in Manaus in 2002 to meet the needs of its clients in the North of the country.

\subsection{Changes adopted for the Manaus market}


INDEPENDENT JOURNAL OF MANAGEMENT \& PRODUCTION (IJM\&P)

http://www.ijmp.jor.br

v. 10, n. 5, September-October 2019

ISSN: 2236-269X

DOI: 10.14807/ijmp.v10i5.926

In the face of the impacts of the global economic crisis of 2008, the sugar and ethanol industry's board asked the commercial and logistics departments for an economic feasibility study on the maintenance of the branch office located in Manaus, whose primary objective was to reduce logistics costs.

Ferreira et al. (2015), for example, cites in his study that every organization should improve its operations by reducing costs and managing risks, which will lead to consumer satisfaction and corporate image improvement.

After the data collection, analysis and results of this study, in 2009 the Manaus branch was deactivated, centralizing its activities in the sugar and alcohol industry in the state of Mato Grosso.

This centralization was mainly motivated by the conclusion of the asphalt paving of the Highway MT 235, in 2009. Besides, another action was the segmentation of the customers that would be served, which went from small retailers to wholesalers and distributors. In this scenario, customers began to purchase larger volumes, which resulted in full loads, reducing the cost and making it possible to receive their products in the Porto Velho River Port, from which point onwards the transportation of the products to their final destination has become the responsibility of buyers. According to the logistics manager, with the transport of crystal sugar being carried out only up to Porto Velho, the costs of this activity were reduced by approximately $50 \%$.

The industry was able to pass on to customers a reduction of $15 \%$ to $20 \%$ in crystal sugar prices, with customers taking over water freight, leaving the sugar and alcohol industry responsible for delivering the cargo in Porto Velho-RO. The advantage to buyers (wholesalers and distributors) of taking over water freight is to reduce the overall costs of their business because they can dilute those costs with other products they resell. Manufacturers located mostly in the South and Southeast of Brazil deliver their products also in Porto Velho, thus enabling the continuation of transportation until the delivery of the products in Manaus.

The sugar and alcohol industry adopted significant alternatives that allowed a new perspective of competitiveness, from the change in freight contracts, reduction of deadlines, allocation of bales in big bags, maximization of physical space, reduction of inventory cost and reduction in the customer response time. 
These changes were adopted through the decision to close the activities carried out at the branch office in Manaus. This strategic decision has gradually favored the reduction of logistics costs. It should be noted that with the benefits of the MT 235 asphalt pavement even with the closure of the subsidiary activities, the industry remained competitive in the market of Manaus, without compromising its revenues, even if there are competitors in the region with intermediate warehouses.

The industry also showed a volume growth in marketed tonnes: $-18 \%$ (2010/09); 41.26\% (2011/10); 10.55\% (2012/11), 3.86\% (2013/12), 31.7\% (2014/13); $39.68 \%$ (2015/14); $53.3 \%$ (2016/15); and 43.5\% (2017/16) respectively, which also favored better integration with its customers.

With the benefits of MT 235 asphalt paving, in 2017 there was a $483 \%$ growth in relation to 2009 of the volume traded, and reducing in the last eight years (20092017), expressive percentages of logistics costs in relation to gross revenues, maintaining an average of $11.58 \%$ ( $\min 8.78 \% \max 13.67 \%$ ). In 2017 , the logistic costs of the sugar and ethanol industry were $12.61 \%$ versus $20.7 \%$ of the Brazilian agribusiness companies (Figure 4).

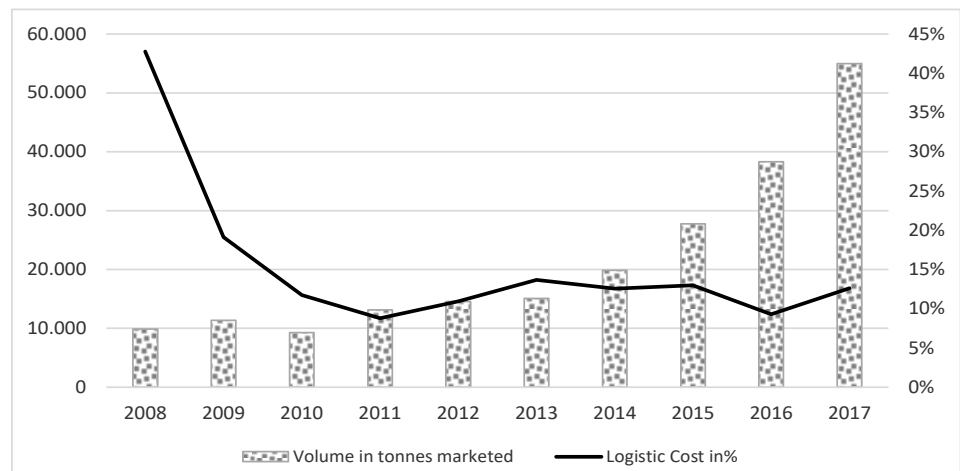

Figure 4: Volume Evolution in tonnes marketed vs. logistic cost in the period from 2008 to 2017.

Source: Research data.

In the year 2017, the Brazilian agribusiness sector recorded logistical costs of $20.7 \%$ against $12.61 \%$ of the sugar and alcohol industry. These results demonstrate that the industry has been able to present satisfactory results when compared to the market in which it is inserted (FDC, 2017). Table 1 presents the strategic performance related to the logistics aspects of the sugar and alcohol industry.

Regarding the issue of highways, the paving of Highway MT 235, is an example of the importance of highways in right conditions, reducing the time of travel 
INDEPENDENT JOURNAL OF MANAGEMENT \& PRODUCTION (IJM\&P)

http://www.ijmp.jor.br

v. 10, n. 5, September-October 2019

ISSN: 2236-269X

DOI: 10.14807/ijmp.v10i5.926

considerably and reducing the maintenance of freight transportation. The factors that tend to increase the logistical cost in Brazil are, mainly, the poor conditions of the highways. For example, the national cost of transportation, which has a significant regional variation, is one of the highest in the world and is four times higher than the transport costs of the United States of America (SILVEIRA, 2018).

Table 1: Evaluation of the strategic performance of the sugar and alcohol industry

\begin{tabular}{|lll|}
\hline \multicolumn{2}{l}{ Measures of performance } \\
\hline Cash flow & - & Elimination of inventory costs of the Manaus branch. \\
\hline Costs Reduction & - & Reduction of transport costs by approximately $50 \%$ \\
& - & Logistic costs below the national average \\
& - & Change in road freight contracts \\
& - & Reduction of lead time \\
& - & Resizing the physical warehouse space of the industry plant \\
\hline Return on Investment & - & Constant volume growth in tonnes marketed in recent years \\
\hline
\end{tabular}

Source: Research data.

In this context, the present study highlights the importance of logistics performance concerning international competitiveness, as well as at the regional level (BASSASSI et al., 2015). Logistics strategies become critical to the minimization of financial and opportunity costs (NUNES; MATSCHULAT; STEINBRUCH, 2016) and the ongoing massive investment program to increase the density and interconnectivity of the national road system is to further promote trade in the export of all types of commodities (TSEKERIS, 2017).

Another aspect is related to the general quality of the highways and, especially, concerning the paving conditions, since they have a direct negative impact on the logistics costs. With the deterioration of the quality of highways, the estimated operational cost can reach $27.0 \%$ (CNT, 2017).

Brazil is late in its policy of investment in logistics infrastructure, as well as in infrastructure generally related to other areas of the economic environment. The various investments give results, but they do not seem to follow the growth dynamics of agribusiness and Brazilian agriculture (COSTA; MARJOTTA-MAISTRO, 2017). On the other hand, the reduction in transport costs resulting from investment in infrastructure contributes to the increase in trade between Brazilian and world regions. In this case, the internal transport infrastructure can play an important role in accessing international markets (COŞAR; DEMIR, 2018).

Low investment in infrastructure must permeate the Brazilian economy. The problems are not limited to an area, but to stretches of highways, for urban 
INDEPENDENT JOURNAL OF MANAGEMENT \& PRODUCTION (IJM\&P)

http://www.ijmp.jor.br

v. 10, n. 5, September-October 2019

ISSN: 2236-269X

DOI: 10.14807/ijmp.v10i5.926

transportation, from ports to generation and transmission of electricity (AMANN et al., 2016).

In particular, the improvement of interregional accessibility and market potential which have a positive impact on agricultural exports by road. The results of this study may offer possible implications for the coordination of regional investment policies and planning of continental transportation systems in connection with the location of logistics centers (TSEKERIS, 2017).

It is noteworthy that only $12.2 \%$ of Brazilian highways are paved (CNT, 2017). The direct relationship between the poor quality of the Brazilian highways and the socio-environmental and economic issues result in serious road accidents that result in deaths and unnecessary diesel consumption that directly affect transport costs, increasing pollution through the emission of pollutant gases harmful to the environment and human health.

\section{CONCLUSION}

The data from this longitudinal case study allowed us to identify that the main responsible for the high logistic cost of the sugar and alcohol industry was due to poor conditions in the MT 235 highway, which increased the operational cost of transportation. The company did not have good conditions to set deadlines, which generated the need to maintain stock in Manaus. The problems included the risk of tipping and jamming of trucks, accidents and unnecessary consumption of diesel. After the asphalt paving, logistical costs were considerably reduced.

In the case of the sugar and alcohol industry, we highlight the reduction of logistics costs, lower lead time in deliveries, better predictability of the delivery period, reduction of transport costs, reduction of breakdowns, which had increased profitability. On the other hand, the industry has two competitive performances: cost and delivery, as competing priorities of high importance.

With the benefits of the MT 235 asphalt pavement, we have found that in 2017 occurred a $483 \%$ growth to 2009 of the volume traded. In the same direction, logistics costs have been significantly reduced concerning gross revenues, maintaining an average of $11.58 \%$. In 2017 logistics costs reached $12.61 \%$ compared to Brazilian agribusiness companies, which was $20.7 \%$. 
DOI: 10.14807/ijmp.v10i5.926

Crystal sugar delivery efficiency is related to the industry's ability to plan, integrate its value chain, and align its strategic and operational processes synergistically. The partnership with its customers was indispensable.

We conclude that investments in road transport infrastructure have considerably reduced logistical costs and have been crucial in fostering trade and competitiveness of products on international markets.

Thus, our longitudinal case study findings have implications for the increase of academic knowledge related to the research topic. Managerial implications for business managers, as an alternative of strategic changes to the logistics processes in order to redirect the businesses that present characteristics similar to those of the investigated sugarcane company, as well as to companies from other economic segments, since logistics has characteristics of universal applications.

\section{REFERENCES}

AMANN, E.; BAER, W.; TREBAT, T.; LORA, J. V. (2016) Infrastructure and its role in Brazil's development process. The Quarterly Review of Economics and Finance, v. 62 , p. 66-73.

ASSIS, A. C. V.; MARCHETTI, D. S.; DALTO, E. J. (2017) Panoramas setoriais 2030: logística. In: Panoramas setoriais 2030: desafios e oportunidades para o Brasil. Rio de Janeiro: Banco Nacional de Desenvolvimento Econômico e Social, 2017.

BALLOU, R. H. (2006) Gerenciamento da cadeia de suprimentos/logística empresarial. 5. ed. Porto alegre: Bookman.

BALLOU, R. H. (2010) Logística Empresarial: transportes, administração de materiais, distribuição física. São Paulo: Atlas.

BENSASSI, S.; MÁRQUEZ-RAMOS, L.; MARTÍNEZ-ZARZOSO, I.; SUÁREZBURGUET, C. (2015) Relationship between logistics infrastructure and trade: Evidence from Spanish regional exports. Transportation Research Part A: Policy and Practice, v. 72, p. 47-61.

BOULOS FILHO, P.; RAYMUNDO, H.; MACHADO, S. T.; LEITE, A. R. C. A. P.; SACOMANO, J. B. (2015) Configurations of tire pressure on the pavement for commercial vehicles: calculation of the ' $\mathrm{N}$ ' number and the consequences on pavement performance. Independent Journal Of Management \& Production, v. 7, n. 5, p. 584-605.

CNT - CONFEDERAÇÃO NACIONAL DO TRANSPORTE (2017) Pesquisa CNT de rodovias 2017: relatório gerencial. Brasília: CNT : SEST : SENAT. Available in: <http://pesquisarodoviascms.cnt.org.br//Relatorio\%20Geral/Pesquisa\%20CNT\%20(2 017)\%20-\%20ALTA.pdf>. Accessed in: 07 jun. 2018.

COOPER, D. R.; SCHINDLER, P. S. (2003) Métodos de pesquisa em administração. 7. ed. Porto Alegre: Bookman. 
COŞAR, A. K.; DEMIR, B. (2016) Domestic road infrastructure and international trade: Evidence from Turkey. Journal of Development Economics, v. 118, p. 232-244.

COSTA, M. S.; MARJOTTA-MAISTRO, M. C. (2017) Indicadores de qualidade da infraestrutura logística brasileira: um estudo para o agronegócio. Revista Brasileira de Iniciação Científica, v. 4, n. 9, p. 67-83.

DEIMLING, M. F.; PARIZOTTO, D.; PAULEK, E. C.; SANTOS, T. A. (2016) Análise da Influência da Logística de Transportes Rodoviários no Custo Brasil. Revista de Administração do Unifatea, v. 13, n. 13, p. 166-188.

FARIA, R. N.; SOUZA, C. S.; VIEIRA, J. G. V. (2015) Evaluation of logistic performance indexes of brazil in the international trade. RAM - Revista de Administração Mackenzie, v. 16, n. 1, p. 213-135.

FAY, M; ANDRES, L. A.; FOX, C.; NARLOCH, U.; STRAUB, S.; SLAWSON, M. (2017) Rethinking Infrastructure in Latin America and the Caribbean: Spending Better to Achieve More. Washington, DC: World Bank.

FDC - FUNDAÇÃO DOM CABRAL. (2017) Custos Logísticos no Brasil - 2017, Nova Lima. Available in: <https://www.fdc.org.br/conhecimento-site/nucleos-de-pesquisasite/Materiais/pesquisa-custos-logisticos2017.pdf>. Accessed in: 05 jun. 2018.

FERREIRA, C. S.; SALGADO, E. G.; SILVA, C. E. S.; MELLO, C. H. P.; SAMPAIO, P. (2015) Reasons and benefits associated with ISO 9001 Certification for sugar and ethanol companies. Independent Journal Of Management \& Production, v. 6, n. 3, p. 623-642.

GAZETA MT. (2018) Chuvas causam atoleiros e interditam três rodovias no Médio Norte; prefeito decreta estado de emergência. Mato Grosso, 26 fev. Available in: <http://gazetamt.net/2018/02/26/chuvas-causam-atoleiros-e-interditamtres-rodovias-no-medio-norte-prefeito-decreta-estado-de-emergencia-ver-imagens/>. Accessed in: 04 jul. 2018.

PORTAL AMAZÔNIA. (2016) Navegação no rio Madeira é restrita entre Porto Velho-RO e Humaitá-AM. Humaitá: Jornal de Humaitá, 19 jun. Available in: https://jornaldehumaita.com.br/2016/07/navegacao-no-rio-madeira-e-restrita-entreporto-velho-ro-e-humaita-am/. Accessed in: 12 jul. 2018.

LOPES, H. S.; LIMA, R. S.; LEAL, F.; NELSON, A. C. (2017) Scenario analysis of Brazilian soybean exports via discrete event simulation applied to soybean transportation: The case of Mato Grosso State. Research in Transportation Business \& Management, v. 25, p. 66-75.

MONTES, G. C.; REIS, A. F. (2011). Investimento Público em Infra-Estrutura no Período Pós-Privatizações. Economia e Sociedade, v. 20, n. 1, p. 167-194.

NUNES, D. P.; COSTA, F.; FREITAS JUNIOR, M.; BUENO, R. E. (2018) Impacto econômico da escolha de modal de transporte para exportação de produto eletroeletrônico. South American Development Society Journal, v. 4, n. 10, p. 117.

NUNES, M. P.; MATSCHULAT, S.; STEINBRUCH, F. K. (2016) Os desafios logísticos das empresas brasileiras em suas operações com a Índia e a África do Sul. Revista de Administração da UNIMEP, v. 14, n. 2, p. 104-128. 
NEVES, M. F. (2018) A greve no transporte e os impactos no agronegócio. Jornal da USP. 05 de julho. Available in: <https://jornal.usp.br/artigos/a-greve-no-transportee-os-impactos-no-agronegocio/> Accessed in: 19 Jul. 2018.

OECD - ORGANISATION FOR ECONOMIC CO-OPERATION AND DEVELOPMENT (2018) OECD Economic Surveys: Brazil 2018. Available in: <http://webexchanges.oecdcode.org/AvQlfTBu/1018041e.pdf>. Accessed in: 07 jun. 2018.

RECH, L. R.; MORAIS, M.; CASAROTTO, E. L.; BINOTTO, E. (2017) Análise situacional das rodovias federais para o escoamento da produção do agronegócio em Mato Grosso do Sul e Mato Grosso. Revista do CCEI, v. 22, n. 37, p. 37-51.

SILVEIRA, M. R. (2018) Transportes e a logística frente à reestruturação econômica no Brasil. Mercator, v. 17, p. 1-20.

SLACK, N.; BRANDON-JONES, A.; JOHNSTON, R. (2017) Administração da produção. 4. ed. São Paulo: Atlas.

SKOROBOGATOVA, O.; KUZMINA-MERLINO, I. (2017) Transport Infrastructure Development Performance, Procedia Engineering, v. 178, p. 319 - 329. Available in: <doi: 10.1016/j.proeng.2017.01.056>. Accessed in: 19 set. 2018.

TOLOI, R. C.; FREITAS JUNIOR, M.; REIS, J. G. M.; VENDRAMETTO, O.; COSTA NETO, P. L. O. (2016) Droughts in the Tietê-Paraná Waterway: impacts on the direct, indirect and hidden costs in the transportation of soybean. Independent Journal of Management \& Production (IJM\&P), v. 7, n. 2, 431-444.

TSEKERIS, T. (2017) Domestic transport effects on regional export trade in Greece. Research in Transportation Economics, v. 61, p. 2-14. Available in: <http://dx.doi.org/10.1016/j.retrec.2016.08.006>. Accessed in: 18 set. 2018.

YIN, R. K. (2010) Estudo de caso: planejamento e métodos. 4. ed. Porto Alegre: Bookman. 